\title{
AN INVESTIGATION OF COMPLIANCE IN TYPE II DIABETIC PATIENTS ATTENDING CLINIC AT CHURCH OF SCOTLAND HOSPITAL.
}

\section{SR Khoza and W Kortenbout}

\begin{abstract}
Thirty Type II diabetic patients attending a clinic at a rural hospital were interviewed, using structured interviews and clinic records. The patients' clinic cards were also used to obtain the required information.

The study was conducted to identify the factors that lead to non compliance with the recommended treatment regimen, to establish whether diabetic patients are able to keep appointments and to identify factors that influence patients from keeping appointments.

Factors that led to non compliance were financial problems and forgetfulness.

Most clients were unemployed while others were pensioners and could not afford the expensive means of transport to the clinic. Additional issues were rough terrain and roads which depended an good weather.
\end{abstract}

The mast common complication found in the study was hypertension, which when combined with minor ailments, led to clients taking multiple medications.

\section{OPSOMMING}

Onderhoude is gevoer met 30 Tipe II diabeetpasiente wat die kliniek by die Church of Scotland Hospital bywoon. Daar is van gestruktureerde onderhoude en kliniese rekords gebruik gemaak. Die pasiente se kliniekkaane is ook gebruik om inligting te verkry. Die studie is onderneem om: die faktore te identifiseer wat lei tot nie-navolging (non-compliance) van die aanbevole behandeling; vas te stel of diabetiese pasiente afsprake kan nakom; faktore te identifiseer wat pasiēnte daarvan weer om afsprake na te kom.

Faktore wat gelei het tot nie-navolging (non-complience) in Tipe II diabeetpasiente wat die kliniek by die Church of Scotland bygewoon het, was:

- finansiele probleme en

- vergeetagtigheid.

Die meeste pasiente was werkloos en sammige was pensioentrekkers wat nie die duur vervoerkoste kon bekastig nie. Bykomende faktore was topografie en paaie wat van die weer afhanklik is.

Hipertensie was die mees algemene komplikasie wat in die studie gevind is. Saan met ander geringe ongesteldhede het dit daartoe gelei dat pasiente veelvudige medikasie geneem het. Veelvuldinge medikasie het weer daartoe dat pasiènte nie vooegeskrewe behandeling geneem het soos verlang nie, as gevolg van newe-effekte soos deur die pasiënte beskryf

\section{INTRODUCTION}

This study was conducted at a clinic nu by the Church of Scotland Hospital in the Msinga area of KwaZulu - Natal. It is a community hospital giving a comprehensive service to approximately 250000 people living in this rural area. The land is rugged with difficult terrain and poor infrastructure; secondary roads become impossible to access in rainy weather. The nearest large town to the hospital is Pietermaritzburg, $190 \mathrm{~km}$ away to the north-east

\section{PROBLEM STA TEMENT.}

Various specialised services are run by the hospital, including diabetic and hypertensive clinics. Special diabetic clinics are directed towards maintaining diabetic patients in a healthy and an idependent way as possible.

Robert $(1993,425)$ states that "...the prevalence of diabetes, particularly of the non-insulin dependent variety, is reaching near-epidemic proportions in many parts of the world, including parts of South Africa". In South Africa, the number of diabetics has been estimated at about 700,000 , taking into account the known prevalence of non-insulin dependent diabetes mellitus (NIDDM or Type II). Several studies show that only about half of the already diagnosed diabetics currently are clinic attenders. (Robertson 1989) NIDDM is by far the most common form of diabetes and usually has its onset in the later adult years. Mortality rates among patients with NIDDM are approximately twice as high as in the non-diabetic population. Atherosclerotic vascular disease accounts for $60 \%$ of deaths with important causes being cerebro-vascular disease and myocardial infarction. (Peden \& McPherson 1990).

It has been observed in this nural hospital that the majority of diabetic patients who get admitted have a history of having been on oral treatment but end up with complications like foot infection, amputation arteriosclemosis and other problems associated with diabetes. This leads to the assumption that non-compliance with treatment is the main reason. (Hentinen \& Kyngas 1992; Branon \& Feista 1988; Cargill, 1992).

\section{OBJECTIVES OF THE STUDY.}

The objectives of the study were:

1. To identify the factors that may lead to non compliance with the recommended treatment regimen.

2. To establish whether diabetic patients are able to keep appointments with the clinic.

3. To identify factors that influence and prevent patients from keeping appointments with the clinic 


\section{THEORETICAL FRAMEWORK}

This study is based on the Basnef model which describes how people interpret the effect of behaviour on performance outcome.

According to Hubley (1988) the acronym BASNEF stands for:-

$$
\begin{aligned}
& \text { B - beliefs } \\
& \text { A - attitudes } \\
& \text { S - subjectivity } \\
& \mathrm{N} \text { - noms } \\
& \text { E - enabling } \\
& \text { F - factors }
\end{aligned}
$$

This model is an endeavor to capture how people interpret behaviour as being good or bad.

People will not perform a given behaviour if they themselves see that it has no benefit to them. It is the person's own judgement of what is a good or bad that matters. We often look at actions from our own point of view as health workers and place too much emphasis on health and medical factors as a reason for action but the community may consider other values as equally or even more important such as economic survival, status, prestige, physical beauty, attractiveness to the opposite sex, conformity to moral or religious orthodoxy, family honour, etc. depending on the values of the prevailing culture.

It is wrong to automatically put the blame for failure of a health education programme on a lack of interest or motivation. A person may intend to perform a behaviour but be unable to carry this out.

Enabling factors such as time, money, equipment, skills, available services play an important part in behaviour e.g. a patient may have a leg amputated or may be old. He wants to go to the clinic for more supplies of tablets but may be unable to do so. He may have no money for transport. (Hubley 1988, 134-138)

A person may intend to change the behaviour but is unable to do so because of enabling factors such as time, money, material resourses, skills and services accessible to him.

Holme \& Tunbridge (1991) suggest that the term attitude should be used for a person's judgement of a behaviour as good or bad and worth carrying out or not. The judgement will depend on the beliefs he has about the consequences of performing the action. If he believes that performing the action will lead to mainly good outcomes then his attitude will be favourable e.8. compliance can be attained if the Type Il diabetic patient believes that adherance to treatment will enable him to lead a normally varied and full life.

A person will be influenced by various persons in his or her social network. Some people will want the person to perform the behaviour, others will not. The term subjective norm is used for the overall perceived social pressure.

The beliefs of a person concerning the wishes of people significant to her will affect her performance of that action or behaviour. The overall social pressure will depend on a person's perceptions of the wishes of the persons who have the most influence, i.e. are most significant in his or her network.

For example the diabetic patient may believe that her friends and health workers wish her to use traditional medicine for her diabetes. She is likely to conform to wishes of those most significant or important to her.

Acconding to Hubley (1988) the person may be influenced by her or his mother, father, husband, wife or others as stated above to perform the behaviour or not which is being refered to as social pressure created by the significant others. The theoretical framework refers to the above as subjective norms.

\section{LITERATURE REVIEW.}

\section{Compliance}

Branon \& Feista (1988) stated that in order for medical advice to beneficially affect the health of the patient, two contingencies must be met.

- First the advice must be accurate.

- Secondly it must be followed.

Both conditions are essential.

III-founded advice, if strictly followed, may introduce new health problems, leading to disastrous outcomes for the compliant patient. Yet excellent advice, based on the most complete and current medical knowledge, is essentially worthless if unheeded.

Branon \& Feista (1988) commented that in general terms the rate of non-compliance to medical or health advice world wide is approximately $50 \%$

Gregor (1987) stated that a patient's perspective will determine his decision to comply. This is substatiated in the health belief model and is one of the most frequently researched explanations of compliance.

An individual's motivation to engage in a health action is based on perceived severity of a condition. To ascertain the direction of action, mdividuals weigh the benefits of available alternatives against perceived costs.

The cost and inconvenience of modication taking and complicated regimens are additional deterrents to compliance. Van $\mathrm{Zyl}$ Smit (1991) mentioned that lack of understanding about medications and dosages as well as lack of supervised practice, are a factor in imcorrect medication self-managed medication.

\section{DIABETIC DIET}

According to Silvis (1992) the diabetic diet is fundamentally a healthy diet, high in complex carbohydrates, and dietary fibre and low in fat. A nutritionally adequate, mixed diet is satisfactory for most people. With diabetes special foods or food supplements are not required. The dietary recommendations directed towands the diabetic population are essentially similar to those recommended by most authorities for the population as a whole.

Education of diabetic patients and their families and also individualised diet and meal planning are essential components in the management of diabetes mellitus. Weight loss and subsequent maintenance of a desirable body weight should be achieved when necessary. Carbohydrates should be unrestricted including a wide variety of fibre rich complex carbohydrates. Total fat intake, especially saturated fat should be restricted.

Omar, Christopher, Motala, Jailal, and Seedat (1987) emphasized diet as the comer stone of therapy in diabetic control regardless of the type of diabetes. Most diabetic patients do not follow prescribed dietary pattens because:

- they do not have sufficient education.

- there is a lack of adequate follow up from health personnel.

- they are not given an individualised diet, but rather a standard "handout" without any explanation.

- cultural and socio-economic factors are not considered by health personnel when advice is given.

- they are not self-motivated or self-disciplined.

Alcohol abuse holds several dangers for the diabetic patient because symptoms of excessive alcohol intake and of hypoglycaemia can be easily confused depending on the severity of each entity. Excessive alcohol intake may result in the skipping of meals. Recovery from hypoglycaemis may be delayed due to alcohol induced inhibition of gluconeogenesis. In some patients on chlopropimide alcohol may cause an unpleasant flushing sensation, sometimes accompanied by severe vomiting

- Alcohol intake should be reduced and the client to be advised not to drink on an empty stomach. (Omar, Christopher, Motala, Jailal and Seedat 1987).

\section{EXERCISE}

Exercise is probably beneficial to people with diabetes, in improving insulin sensituvity. It is regarded as an important part of life by many people, particularty the young. Unfortunately, exercise can cause problems of blood glucose 
control in inadequately controlled diabetic patients using insulin. (Holme and Tunbridge 1991)

\section{DIA BETIC FOOT.}

Holme and Tunbridge (1991) mentioned that the foot problem in diabetic patients causes more in-patient bed occupancy than all other medical problems put together. Amputation causes major disability and quite often both limbs may need to be amputated. These authors believed that foot problems are largely preventable by giving suitable, repetitive education and advice.

Keen and Jarret (1982) stated that poor hygiene and poorly controlled diabetes are the most important contributing causes of foot problems.

\section{OBESITY}

Obesity is more common in patients with Type II diabetes. Day (1992) stated that there is a high correlation between the degree of obesity in a population and the prevalence of diabetes mellitus. Genetic predisposition and obesity can lead to NIDDM or genetic predisposition may lead to obesity.

\section{NEPHROPATHY}

Holme and Tunbridge (1991)stated that causes of nephropathy include vascular insuficiency and high blood sugar levels which lead to metabolic disturbences within the nephron itself.

There is a need for carly identication of this potentially fatal complication.

Sandle (1989) stated that clinical diagnosis of diabetic nephropathy relies on detection of persistent proteinuria

Van Zyl Smit (1991) mentioned that controlling an elevated blood pressure is the single most effective way of retarding the rate of renal function loss in diabetic nephropathy and should be aggressively persued in all patients.

\section{METHODOLOGY}

This is a descriptive study which used a structured mterview tool. The study was designed to take into account the experiences of Type II diabetic patients attending the diabetic clinic at a Church Of Scotland Hospital. Clinic records were used to elicit the information which could not be gathered by using the structured interview tool.

\section{SAMPLE}

The population consisted of all Type II diabetic patients attending a clinic at the Church of Scotland Hospital. A convenience sample of thirty (30) diabetic patients were selected from all those patients who were Type II diabetic patients and who attended this clinic. The clients were attending the clinic on a weekly besis on Thursdays.

\section{INSTRUMENT AND DATA COLLECTION.}

The structured interview tool was used to interview clients in the clinic on Thursdays. Clinic records and patients' cards were also used to aquire information which could not be supplied by the clients.

The permission to undertake this study was obtained from the relevant authorities of the Department of Health KwaZulu, and from the medical superintendent of the Church Of Scotland Hospital.

Consent for participation in the study was obtained from each patient prior to the interview.

Each patient was informed verbally that the interview was voluntary, and that even after the interview had begun, the client was froe to refuse to answer any question and/or to terminate the interview at any point.

The clients were told that answers to the questions will not be supplied to anyone else, and that no report of this study will ever identify the clients in any way.

Clients were informed that they would receive no direct benefit from their perticipation

\section{CONSTRUCT VALIDITY.}

According to Polit and Hungler (1991) construct validity is done to assess whether there is adequate measuring of abstract concepts under investigation. Lobiodo-Wood and Haber $(1990,40)$ stated that constrct validity attempts to validate a body of theory underlying the measurement. Bellack and Hersan $(1984,40)$ further explained that there is no prescription for determining construct validity. It is established by showing that a measure is related in a systematic way to the focus of interest

In order to meet the above mentioned measures in this study the definition of concepts was done to guide the data collection. Basing the interview tool on the literature also contributed to validity.

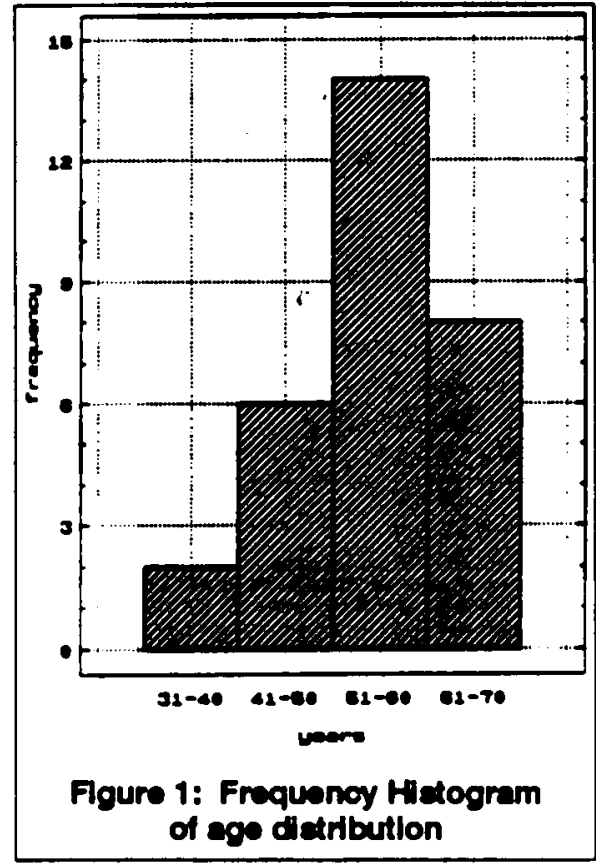

\section{RELLABITY.}

According to Best and Khan $(1993,203)$ reliability is the degree of consistency that the instrument or procedure demonstrates. Whatever it is measuring, it does so consistently.

This was achieved by using the structured interview tool, clinic records and patients' cards. When used repeatedly these three processes produced similar results.

\section{ANALYSIS AND FINDINGS.}

The results were presented in relation to the structured interview tool as it tried to elicit the factors influencing compliance with the recommmended treatment and diet

The results were also interpreted according to the conceptual framework of the Basnef model which considers the enabling factors, subjective norms, beliefs and attitude of people.

Age distribution pattern as displayed in Figure 1 confirms what Charlotte, Murray, and Ponte (1988) stated that Type II diabetes mellitus tends to be present in obese people over the age 40 years. 
The aged person may intend to comply with treatment regimes but due to disabling factors might be unable to do so. Hubley $(1988,134)$ indicated that ailments of the aged, such as partial blindness or painful knees, may contribute to non-compliance.

\section{INCOME LEVEL.}

Level of income of the clients has an impact on compliance with diet and treatments. Thirty percent of the clients stated that financial problems contributed to their inability to follow their prescribed diets and treatments.

Silvis (1992), Peden and McPherson (1990) and Holme (1989) indicated that a reduction in energy intake produces an early fall in blood glucose concentration and an improvement in symptoms caused by hyperglycaemia.

\section{AGE AT TIME OF DIAGNOSIS}

Twenty-seven percent of patients were diagnosed when they were between 41 - 50 years of age. Fifty-seven percent of clients were diagnosed between 51 - 60 years of age Sixteen percent of clients were diagnosed between $61-70$ years of age.

These findings confirmed what Holme and Tumbridge (1991) stated that NIDDM is by far the most commmon form of diabetes and usually has its onset after the age of 40 .

\section{REASONS FOR TRANSPORT PROBLEMS.}

The reasons that were given by the clients included roads which were weather dependent. The study showed that during the rainy days few clients attended the clinic. This caused clients to attend clinic when they had run out of medication

\section{COST FACTOR}

Fifty seven percent of clients considered the cost of travelling to the clinic as too much. Some were unemployed and had no money while pensioners got their money on alternate months.

\section{MULTIPLE MEDICATION.}

Multuple medication could cause patients to omit prescribed treatments. Some clients stated that multiple medication caused toxic effects such as vomiting, nausea, headache and dizziness. This caused clients to discontinue their treatments before consulting the health practitioners. According to Cargill (1992) the complex health problems of older people and their prescription regimes can potentiate the harmful effects of a medication regime and non-compliance.

According to the conceptual framework developed attitudes and beliefs lead to a person performing or not performing the desired behaviour. Negative attitudes towards multiple medication led to clients not complying with the prescribed treatment and diet.

\section{COMPLIANCE.}

Thirty-percent of chets indicated that more than six tablets were left in their packages because they forgot to take tablets sometimes. The reasons given for this were

- forgetfulness.

- multiple medication.

- financial problems.

\section{EATING PATTERNS.}

All clients were taking breakfast, lunch and supper and very few were taking snacks during the morning, afternoon or evening. Although forty percent of the clients stated that diet was the topic most emphasized in the clinic, many clients were not taking snacks.

Twenty percent of the clients stated that failure to foliow their diet was due to lack of self discipline e.g. taking tea with sugar instead of with sweetners even if they were available

\section{ALCOHOL USE.}

Thirty-three percent of the clients were taking alcohol. All were unaware of the dangers of alcohol. Omar, Christopher, Motala, Jailal and Seedat (1987) stated that recovery from hypoglycaemia may be delayed due to alcoholinduced inhibition of gluconeogenesis.

\section{ADDITIONAL FACTORS.}

Whilst conducting the research it was observed that clients waited for a long time to be attended to in the clinic

The clinic day is once per week on Thursdays, from $07 \mathrm{hoo}-14 \mathrm{~h} 00$, there was one registered nurse to see the clients, and one doctor to see the clients. Time spent with the clerk was thirty minutes to one hour

Time spent with the registered nurse was approximatetly forty minutes to one hour, time spent with the doctor was ten to fifteen minutes and time spent while waiting for the laboratory results ranged from one to two hours.

The total amount of time spent in the clinic was approximately three hours and forty minutes.

\section{RECOMMENDATIONS AND CONCLUSION.}

1. The clinic booking system noeds to be revised to avoid long waiting periods. Snacks should be provided in order to meet the nutritional needs of the diabetic patients, who spent up to four hours at the clinic

2 There is a need for in-service education for health professionals who manage the diabetic patients, to improve the education of patients. The inadequacy of nurses was shown when respondants indicated that they were never given health education on topics such as shaking out their shoes before wearing them.

The education of diabetics needs to be planned and implemented according to their needs. Frequent evaluation of the effectiveness of teaching should be implemented.

3. Nutrition and dietary advice should be included in health education of the clients. A follow up, by means of home visits, should be done in order to give appropriate advice based on available resouces in the patient's home surroundings.

4. Families, friends, religious groups, womens' clubs and other social groups could be actively involved in the teaching and counselling of the diabetic pateints. Friends also play an important role in the prevention of self destructive behaviours such as alcohol consumption and smoking.

The study revealed that diabetic care in a poverty stricken population is a challenge as people are faced with many social and economic problems.

\section{REFERENCES}

Bellack, A. S. \& Hersen, M. (1984): Research methods in clinical psychology.Perganon Press: New York.

Branon, L \& Feista J, (1988) : Health psychology. An introduction to behaviour and health. California: Wadsworth

Brodof, B. N. \& Bleicher, S. J. (1982) Diabetes mellitus and obesity. Williams \& Wilkins: Baltimore.

Cargill, A. M. (1992): Medication compliance in elderly people. Influencing variables and intervention. Joumal of advanced mursing. 17, 422-426.

Charlotte, N. Murray, S. \& Ponte, C. (1988): The difference between Typel and Type Il diabetes mellitus. Nursing II 121-123.

Day, J. L. (1992): Diabetes education Turning theory into practice. Diabetes. XIII, 7-8

Hardy, M. E. \& Conway, E.M (1978): Role theory perspective for health professionals. Appleton Century Croft: Norwalk: 
Hentinen M. \& Kyngas H. (1992) : Compliance of young diabetics with health regimens. J. Ad. Nurs. 18, 530-36.

Holmes, S. (1989): Diet and heart diseases. Nursing. Vol. III No.36.

Holme, P. D. \& Tumbridge, W. M. (1991): Diabetes and endocrinology in clinical practice. Edward Amold: London.

Hubley, J. (1988): Understanding behaviour. The key to successful health education. Tropical Doctor. 134-138.

Joshi, P. (1991): Coronary artery diseases and diabetes mellitus. V.M.O. C.M.E. 9.2

Jourbert P. H. (1989): Use of oral agents in diabetes mellitus.V.M.O.C.M.E. 7. 4. 425

Keen, R. \& Jarret, J. (1982): Complications of diabetes. 2nd (ed) Edward Arnold: London.

Levitt, N. S. (1991): The diabetic nephropathies. V.M.O.C.M.E. 9. 2. 161-167.
Lobiodo - Wood, G. \& Haber, J. (1990): Nursing research. Methods critical appraisal and utilization. (2nd ed) Mosby Company: Toronto.

Omar, M. A. K, Christopher, L, Motala, A. A., Jailah, I \& Seedat, M. A. (1987): Management of diabetes mellitus SAMJ 71. 9. 580-587.

Peden, N. R \& McPherson, J. M. (1990): Diabetes: The overweight non insulin dependent patient. Update. 73-83.

Polit D. F. \& Hungler B. P. (1991): Nursing research: principles and practice. 4th ed. Philadelphia: Lippencott.

Robert, T. (1993): Management of diabetes mellitus. Update 203-206.

Robertson, L I (1989): Diabetic care at primary health care level. V.M.O.C.M.E. 7 4. 123-124

Sandler, M. (1989): Early detection of diabetic complications. V.MO.C.M.E. 7.4
Sllvis, S. (1992): Nutritional recommmendations for individuals with diabetes mellitus. SAMJ. 81. 162-166.

Van Der Merwe, T. \& Wing, J. R. (1991): The diabetic foot assessment and management. V.M.O. C.M.E. 9. 2 . 205-208.

Van Zyl Smit, R. (1991): Diabetes and kidneys. VM.O.CM.E. 9. 2. 161-167.

\section{Susan Rita Khoza M.CUR University of Natal DURBAN}

W. Kortenbout B.Soc.Sc. (Nursing) Ph. D (Natal)

Department of Nursing UNIVERSITY OF NATAL DURBAN 